IRSTI 16.41 .39

\author{
S.M. Dadras ${ }^{1 *}$, O. Izadi $^{2}$, S. Rezaei ${ }^{3}$ \\ ${ }^{1}$ Urmia University, Urmia, Iran \\ ${ }^{2}$ Allameh Tabataba'i University, Iran, Tehran \\ ${ }^{3}$ Sharif University of Technology, Tehran, Iran \\ *e-mail:sm.dadras@urmia.ac.ir
}

\title{
THE ORIGINS OF THE TERM “LURI LANGUAGE": A HISTORICAL INVESTIGATION
}

The present article deals with the controversial relationship of Luri Language with Persian, and aims to find out whether Luri is a distinct family from Persian even in the middle period, or it must be considered only a modern dialect of Middle Persian. Based on historical evidence and from a diachronic point of view, the authors put forward the theory that not only isn' $t$ there a single language as Luri but the so-called Luri varieties are in fact modern daughter languages of Middle Persian. This idea is largely based on the previous literature on Luri, but also supported by other findings presented in this article. The mutual intelligibility break among Luri varieties, the lack of reference to Lur tribe in the historical sources of the early Islamic centuries, the etymology of the word "Lur", and the historical accounts of Luri language provide the main arguments and sources of evidence in support of the above theory which are complemented by a grammatical comparison between Luri and historical stages of Persian language.

Key words: Luri Language, Early New Persian, Middle Persian, Dialectology, Historical Linguistics

\author{
C.M. $\triangle а \mathrm{Apac}^{1 *}$, О.ИзаАи², С.Резаи ${ }^{3}$ \\ 'Университет Урмия, г. Урмия, Иран \\ 2Университет имени Аммаме Табатабаи, г. Тегеран, Иран \\ ${ }^{3}$ Технологический университет имени Шарифа, г. Тегеран, Иран \\ *e-mail: sm.dadras@urmia.ac.ir \\ Происхождение термина «языка мури»: \\ историческое исследование
}

\begin{abstract}
Настоящая статья посвящена спорным отношениям языка кури с персидским и ставит своей целью выяснить, является ли кури отАельной семьей от персиАского Ааже в средний периоА, или же его следует рассматривать только как современный диалект среднеперсидского. Аури - это новый иранский язык, на котором говорят племена мур - мигрирующие или оседлые-на обширной территории юго-западного Ирана, в провинциях Аорестан, Чахар-Маха^ и Бахтиари, Хузестан, Исфахан, кохгилуйе и Бойер-АхмаА, а также Фарс. Основываясь на исторических свидетельствах и с диахронической точки зрения, авторы выАвинули теорию о том, что не только нет еАиного языка как мури, но и так называемые разновидности лури на самом деле являются современными дочерними языками среднеперсидского. Эта идея в значительной степени основана на предыдущей митературе по Аури, но также подтверждается и другими выводами, представленными в этой статье. Разрыв взаимной понятности межАу разновидностями кури, отсутствие упоминания племени кур в исторических источниках ранних исламских веков, этимология слова “мур " и исторические описания языка мури дают основные аргументы и источники Аоказательств в поААержку вышеупомянутой теории, которые Аополняются грамматическим сравнением межАу мури и историческими этапами персидского языка.
\end{abstract}

Кмючевые слова: язык мури, ранний новоперсидский, среднеперсидский, диалектология, историческая мингвистика.

\author{
С.М. Дадрас ${ }^{1 *}$, О.Изади ${ }^{2}$, С.Резаи ${ }^{3}$ \\ 'Урмия университеті, Иран, Тегеран қ. \\ ${ }^{2}$ Амламе Табатабаи атындағы университет, Иран, Тегеран к. \\ ${ }^{3}$ Шарифа атындағы технологиямық, университет, Иран, Тегеран қ. \\ *e-mail: sm.dadras@urmia.ac.ir
}

«Аури тікі» терминінің пайда болуы: тарихи зерттеу

Бұл мақала кури тілінің парсы тілімен даулы мәселелеріне арналған және муридің парсы тілінен бөлек тілдік отбасы екенін, тіпті орта кезеңде де, немесе оны тек қазіргі орта парсы диалектісі ретінде қарастыру керектігін анықтауға бағытталған. ^ури - Иранның оңтүстік- 


\begin{abstract}
батысындағы кең территорияда, Аорестан, Чахар Маха^ және Бахтиари, Хузестан, Исфахан, кохгилуйе және Бойер Ахмад провинцияларында, сондай-ақ Фарста лур тайпалары сөйлейтін жаңа иран тілі болып саналады. Тарихи дәлелдерге сүйене отырып және диахрондық тұрғыАан алғанда, авторлар лури сияқты бірыңғай тіл ғана емес, сонымен қатар ^ури деп аталатын тіл іс жүзінде орта парсы тілінің қазіргі заманғы тілдері болып табылады деген теорияны алға тартты. Бұл идея негізінен мури туралы алдыңғы әдебиеттерге негізделген, бірақ сонымен бірге осы мақалада келтірілген басқа да тұжырымдармен расталады. Ерте ислам ғасырларының тарихи деректерінде кур тайпасы туралы ескертудің болмауы, "^ур" сөзінің этимологиясы және лури тілінің тарихи сипаттамалары жоғарыда аталған теорияны қолдайтын негізгі дәлелдер мен дереккөздерін береді, олар лури мен парсы тілінің тарихи кезеңдері арасындағы грамматикалық, салыстырумен толықтырылады.
\end{abstract}

Түйін сөздер: ^ури тілі, ерте Жаңа парсы, орта парсы, диалектология, тарихи кингвистика.

\section{Introduction}

Luri is a New Iranian Language that is spoken by Lur tribes - migratory or settled - in a vast area of southwestern Iran, i.e. provinces of Lorestan, Chahar Mahal and Bakhtiari, Khuzestan, Isfahan, Kohgiluyeh and Boyer-Ahmad, and Fars. It is also reported that a small ethnic population of the Lurs lives in southeastern Iraq (see: Anonby, 2003, p. 171). This language, along with Persian, belongs to the southern branch of the family of western Iranian Languages. After Persian, Luri is geographically the most wide-spread member of the branch, a fact that places importance on investigations into the relationship between the two. While other southwestern languages or dialects of Iran, including Fars dialects, are confined to small regions such as remote villages and towns, Luri speakers are spread on the map of Iran. It seems that in the new period, diverse groups of southwestern dialects have undergone two major currents of assimilation: one leading to the emergence of New Persian, and one other resulting in the development of Luri. However, it must be noted that there is not a single language as Luri, and as some linguists have proposed, Luri is a "language cluster" (Anonby, 2003, p. 171) comprised of several related languages including Feyli (Luristāni), Bakhtiari and BoyerAhmadi as the major varieties. ${ }^{(1)}$ The present article, based on the previous literature on Luri, attempts to address the contentious issue of the relationship of Luri dialects with Middle Persian from a historical point of view.

\section{Literature Review}

The first serious documentation of Luri language has been carried out by the Russian scholar, V. A. Zhukovski (1922), at the end of the $19^{\text {th }}$ century (1883-1886). He transcribed 992 oral
Bakhtiari couplets in his famous dissertation, Materialy dlya izučenija persidskix narečij. Despite the large bulk of these materials, Zhukovski remains silent about the genealogical classification of Bakhtiari.

After Zhukovski, the German linguist, O. Mann (1910) studied Luri in Die Mundarten der Lurstämme - although his work was published before Zhukovski's. Mann was the first to distinguish Luri, that was thought to be a dialect of the latter back then (Minorsky, 1986, p. 823), from Kurdish.

W. Thackston of Harvard University ${ }^{(2)}$ according to Amanolahi-Baharvand $(1385$, p. 53) believes that "Luri language has evolved from Persian language nearly or less than one thousand years ago".

Sadeghi (2003, p. 20) considers Luri as "one of the branches derived from Middle Persian".

Windfuhr and Perry (2009, p. 418), though pointing to the Early New Persian origin of some Luri features, classify Luri as Perside and say that:

In SW [South Western] Iran there are two groups which can be recognized as "Perside", i.e. they continue numerous features that evolved from Southern Early New Persian ... though each evolved differently: (1) The Luri-type dialects ... (2) The Fars dialects.

A comprehensive study of Luri grammar has been done by MacKinnon (2011), based on which he has come to the conclusion that:

All Lori dialects closely resemble standard Persian and probably developed from a stage of Persian similar to that represented in Early New Persian texts written in Arabic script. The sole typical Lori feature not known in early New Persian or derivable from it is the inchoative marker, though even this is found in Judeo-Persian texts. There is furthermore no need to assume a common "protoLor" stage for the dialects grouped under the term Lori. NLori [Northern Lori] and SLori [Southern 
Lori], though they share many features, probably developed separately though along parallel lines. Despite their similarities to standard Persian, the Lori dialects share features that set them apart as a group from the standard language. It is in their phonology that the Lori dialects diverge most noticeably from Persian.

Anonby (2003, p. 177), unlike Sadeghi and MacKinnon, questions the evolution of Luri from Persian:

There is still a widely-held perception among Farsi-speaking Iranians that Luri is simply an "accent" or "dialect" of Farsi. However, linguistic and sociolinguistic research has demonstrated that Luri may indeed be considered language in its own right. In other words, it shows a great deal of differentiation from Farsi in the areas of phonology, morphology, grammatical and semantic structure as well as lexicon; and speakers are aware of this distinctness. Furthermore, the two varieties are not inherently intelligible with one another, a fact which is obscured by a high degree of bilingualism in Farsi among the Luri population. Because of these factors, there is little academic literature that presently supports the classification of Luri as a Farsi dialect.

Anonby (2003, p. 182) further argues that: "Luri is best classified as a language continuum between Kurdish and Farsi varieties, and is itself composed of three distinct languages: Luristāni, Bakhtiāri and Southern Luri". However, he accepts the classification of Luri as Perside:

Lori varieties have been classified as part of the "Perside" group, itself parallel to Persian and Persian varieties within the Southwest subgroup of West Iranian. Alongside Lori, other members of the Perside group include Dezfuli-Šuštari as well as Davāni, and a heterogeneous ensemble of other Fārs dialects (Anonby, 2012).

\section{Methodology}

In the following sections, the main theory of the article is discussed with three historical approaches. The first section (4.1), which contains a brief hisory of Luri, is written from a historiographical standpoint. Section 4.2 attempts to explain former historical facts by employing a sociohistorical approach, giving way to the main and last discussion, i.e. geneology which has purer linguistic essence. We strongly believe that any research into the problem of Luri must take into consideration all these three aspects as the diversity of the previous literature reveals.

\section{Discussion}

Historical Accounts of Luri Language

Our knowledge of the history of Luri language is very poor, since Luri, just like many Iranian languages, suffers from the lack of a writing tradition. The oldest surviving Luri manuscript dates back to the $11^{\text {th }}$ Islamic century, and contains only 3 pages, written in Perso-Arabic script (see: Sadeghi, 1996). Except for this short text, there are no other pre-modern Luri texts known to us. However, thanks to historians' brief accounts, we can trace Luri further back in history. Tärikh-i Guzida (written in 730 AH/1330 AD) by Hamdallah Mustawfi is the oldest source to use the term "Luri language" (Sadeghi, 1996, pp. 9-10). Mustawfi has claimed that the Persian letters

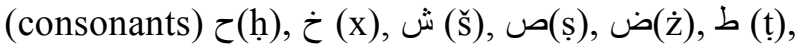
ظ(z), ع ( $\left.{ }^{\circ}\right), \dot{\varepsilon}(\gamma)$ and $(\mathrm{q})$ do not exist in Luri language. This description, to some extent, reminds us of features of modern Luri dialects. For example, in some Bakhtiari ${ }^{(3)}$ words, like har 'donkey', $h \bar{a} r$ 'thorn', horm $\bar{a}$ 'date', the consonant $/ \mathrm{h} /$ corresponds to the Persian $/ \mathrm{x} /$. In the following Bakhtiari examples, /k/ has replaced the Arabic /q/: ${ }^{(4)}$ xolk 'temper', xalk 'people', halken 'hoop', kuwāre 'bulk' and kad 'hight' (Ar. xulq, xalq, halqa, quwāra, qad). As to $\bar{\omega}$ and $\dot{\xi}$, it appears that Mustawfi's statement is an inductive generalization based on the following lexical items: -es 'his', -esūn 'their', angost 'finger', (') most 'fist', ${ }^{(6)} s \bar{u} r$ 'salty', ${ }^{(7)} p \bar{e} s$ 'before', čāst 'afternoon' (Mn. P. -eš, -ešun, angošt, mošt, šur, piš, čâšt $)$. Contrary to Mustawfi's claim, in a number of Luri words the consonant $/ \check{s} /$ corresponds to the Persian /s/. For instance, in the Bakhtiari words šošten 'to wash', hākeštar 'ash', ferešnāden 'to send', šātīl 'cleaver', šah 'black', šìt 'whistle', šelìte 'shrewish' (cf. Mn. P. šostan, xâkestar, ferestâdan, sâtur < Ar. sātūur, siyah, sut, salite < Ar. salīta). Likewise, the Bakhtiari words čerā 'lamp', dorō 'lie', $d \bar{u}$ 'yogurt drink, doogh' and kalā 'crow' might have led him - or maybe his oral sources to make such a generalization about the consonant $/ \gamma /$ (cf. NP: čir $\bar{a} \gamma, d u r \bar{o} \gamma, d \bar{u} \gamma, k a l \bar{a} \gamma)$.

The above account of Luri language proves that Luri had developed into a distinguishable language by the beginning of the $8^{\text {th }} / 14^{\text {th }}$ century. Yet, there is still no evidence for the existence of Luri in preIslamic Iran. Daryaee (2009, p. 101) when describing the language diversity of Sasanian Persia, names Luri and Kurdish as speculative languages of that era: 
these are the only languages of which we have some information and there were many more dialects and languages which have been lost to us. The nomadic people and their languages are more difficult to gauge, but certainly the Kurds had been present on the plateau, and Kurdish, with its various dialectal variances, existed, perhaps along with Luri and few others which have been lost.

Another piece of historical evidence for Luri language is the Arabic term rițāna(t) /rațāna(t) (الرطانة) 'speaking in an unintelligible way, to speak a non-Arabic language'. The term has been used in Nukhbat al-dahr, another $8^{\text {th }}$ century book, to describe the language of a region named $L \bar{u} r$ (لور). According to historical sources, Lūr - or Bilād allür (بلاد اللور) - was somewhere between Khuzestān province and Isfahān city, where today's Lur tribes inhabit. Thus, it is believed that the name Lur is originally derived from the name of the region. Although the geographical meaning of Lur dates back to the $4^{\text {th }}$ Islamic century (AmanolahiBaharvand, 1385, p. 15), there is no mention of the Lur tribes prior to the $5^{\text {th }}$ century. The earliest attestation of Lur as a tribe belongs to Vìs $u$ Rāmin, a famous versified Persian story of the $5^{\text {th }}$ century (see: Dehkhodâ, 1373, pp. 17482-17483):

$$
\begin{aligned}
& \text { جهان آسوده كَثت از دزد و طرّرّار }
\end{aligned}
$$

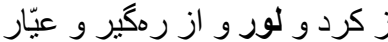

(Fakhraddin Gorgani, 1381, p. 367. Translation: The world was saved from thieves and pickpockets, from the Kurds and the Lurs, and from bandits and Ayyārs).

The author of Nukhbat al-dahr describes the language of the region of $L \bar{u} z$ (لوز)-definitely a corrupt form of $L \bar{u} r$ - using the above-mentioned rițāna $(t)$ :

و حيّز اللوز و هم بجبل متّصل بجبال إصفهان طوله سبعأ أبّام

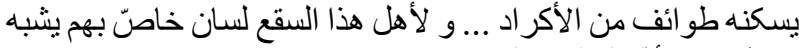

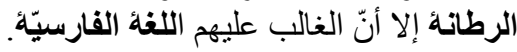

(Al-Dimashqi, 1923,p. 179. Translation: and the region of Lūz, its people live in a mountain attached to Isfahān mountains with a length of seven days in which tribes of Kurds ${ }^{(8)}$ live ... the people of this region have their own language which resembles rițana(t), although their dominant language is Persian).

According to the above account, we can conclude that the residents of Lūr spoke a distinct dialect which might have been close to Persian. The pertinence of ritanna(t) to Persian is confirmed in a way by an old Arabic-Persian dictionary from the $6^{\text {th }}$ century AH:

\section{الرَّطانَةُ: بارسى كفنتن.}

(Karamainî, 2006, p. 264. Translation: arrațānat-u: to speak Persian).

A Sociohistorical Approach

Anonby (2003), in his study of Luri dialects, concludes that the differences between these dialects are so remarkable that in practice they must be considered separate languages. MacKinnon (2011) prefers to assume different origins for the different Luri dialects as well. He also classifies Dezfuli and Shushtari - which are traditionally known as Persian dialects - as members of the Luri family. This leads us to the idea that the only reason Dezfuli and Shushtari are often accepted as Persian dialects is that there are no tribes named Dezfuli and Shushtari. As MacKinnon has correctly recognized, the large similarities between Luri and the two mentioned dialects suffice to put them in the Luri group, although they have their own distinguishing features. This suggests that the term Luri Language comes particularly from tribal divisions, rather than linguistic facts. As mentioned in section 4.1, the word Luri is probably derived from $\operatorname{Lu} \mathrm{r}^{(9)}$ which, according to early Islamic geographical sources, was the name of a region. It sounds plausible that medieval Iranians might have broadly called the whole nomads of the region the Lurs, regardless of their native or tribal affinities. Consequently, the Languages of the Lur were named Luri - literally meaning 'attributed to Lur' - by non-Lurs being unaware of its linguistic diversity. Ironically, we can assume that the socalled Lur tribes gradually began to identify with this newly forged identity.

The emergence of the tribes known as the Lurs is a historical mystery. Unlike the Kurds and other ancient ethnic groups of Iran, there is no trace of the Lurs in Old and Middle Iranian texts. Considering the vast area in which Modern Luri is spoken, it is expected to stumble upon mentioning of the Lur tribe or Luri language in Middle Persian texts, for the language territory of Pahlavi language included today's Luri-speaking regions, i.e. southwestern Iran. In fact, were there a proto-Luri in the Middle period, it would have been possibly mentioned in pre-Islamic sources, or at least in the earliest Muslim historians' accounts of Iranian Languages. Nonetheless, in reality, it is in the manuscripts of the $5^{\text {th }}$ Islamic century that we find the first mention of the Lur tribe (see: section 4.1). Interestingly, the first attestation of Luri language appears three centuries later. Therefore, it can be concluded that the coining 
of the term Luri Language might have been a result of the appearance of the Lur tribes.

The scarcity of the pre-modern Luri manuscripts is another fact to be considered from a social viewpoint. An explanation, though not strong, for this phenomenon is that if there were a gap between Luri and Persian in early Islamic Iran - as was the case with Tabari, Fahlavi and Shirazi Languages there could have been more written evidence of premodern Luri, especially on account of its geographical extent.

\section{Genealogy}

From a synchronic point of view, every Luri variety alone, based on grammatical features, is a distinct language from Modern Persian. The criterion of "mutual intelligibility" confirms this classification to some extent. However, this gap seems to disappear when we take into account the historical periods of Persian Language, namely Middle and Early New Persian. MacKinnon (2011), as mentioned in section 2, believes that Luri and Persian unite at some point in the distant past, where they were no longer separable:

It is striking that Lori dialects, like Middle Persian but unlike standard Persian, do not use verbs of motion such as šodan, gaštan, amadan and the like to indicate change of state or process ... It is also striking that unlike Standard Persian no Lori dialect uses the stem $b \bar{a} \breve{s}$ - to indicate subjunctive or imperative of "be." (Middle Persian uses $b \bar{a} \check{s}$ - as an imperative, though not a subjunctive stem).

The above examples are only a handful of many common structures between Luri and Middle Persian. Table 1 gives a list of the Bakhtiari forms of Middle Persian verbal inflectional affixes not used in Modern Persian:

Table 1 - Verbal inflectional affixes in Bakhtiari, Modern Persian and Middle Persian

\begin{tabular}{|c|c|c|c|}
\hline & MP & Bakhtiari & Mn. P \\
\hline Negative Imperative & $m a-$ & $m a-$ & $n a-$ \\
Optative & $-\bar{e}$ & $-\bar{e} /-a y$ & \\
Passivizer & $-\bar{\imath} h-$ & $-e h-$ & $-\hat{e} n-(\mathrm{cf}$. Parthian $-\bar{a} n-)$ \\
Causative & $-\bar{e} n-$ & $-(e) n-$ & $-\operatorname{an}(d)$ \\
\hline
\end{tabular}

The above suffixes -ìh- and -èn- are also found in Early Jewish-Persian texts (for examples, see: MacKenzie, 1968, p. 258) which are distinguished by their MP features:

Up to the 11 th or early 12 th century, these EJP documents preserved MP grammatical features and lexemes that had already vanished from contemporaneous Dari New Persian in the northeast... There is no evidence to prove that the Jews and Zoroastrians of southern Iran considered the form of Persian they used during the 8th-11th centuries as a "new" form of Persian detached from (late) Middle Persian. They continued to call their language Pārsī $(<\mathrm{MP}$
Pārsīg) well into the 11 th century and beyond... While many of the EJP texts written in Hebrew script are from southwestern Iran (e.g., Ahvāz) [see: Asmussen, 1965], a dialect translation of the Koran found in the 1970s was produced in the southeast (Sistān), probably in the early 11 th century (Paul, 2013).

The Feyli plural suffix $-y \bar{a}$ (cf. Mn. P. $-(h) \hat{a}$ ), which is obviously a new form of the EJP MP. -īha ) (for examples, see: MacKenzie, 1968, pp. $260 \& 262),{ }^{(10)}$ plainly illustrates how Luri and Mn. P. could have evolved differently from the same origin, i.e. Middle Persian. Pronouns are other common lexical items in Luri and EJP:

Table 2 - Common pronouns in Luri and EJP

\begin{tabular}{|c|c|c|c|c|}
\hline & EJP & Bakhtiari & Feyli & Dezfuli \\
\hline $\begin{array}{c}1^{\text {st }} \text { Person Plural Pronoun } \\
2^{\text {nd }} \text { Person Plural Pronoun }\end{array}$ & $\begin{array}{c}\bar{\imath} m \bar{a} n \text { (cf. NP. } m \bar{a} \text { ) } \\
\check{s} u m \bar{a} n \text { (cf. NP. } \check{s} u m \bar{a})\end{array}$ & $\bar{\imath} m \bar{a}$ & $\bar{\imath} m \bar{a}$ & $\begin{array}{c}\text { omūn } \\
\check{s} \text { omūn }\end{array}$ \\
\hline
\end{tabular}


Luri also shares phonemes and an allophone with

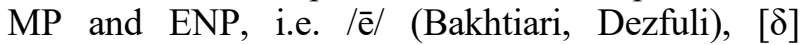
(Bakhtiari, Southern Luri) and $/ \gamma /$, plus the controversial diphthongs of [au] and [ai] (Bakhtiari), the long vowels $/ \overline{\mathbf{1}} /, / \overline{\mathrm{a}} /$ and $/ \overline{\mathrm{u}} /$ (corresponding to the Mn. P. $/ \mathrm{i} /, / \hat{\mathrm{a}} /$ and $/ \mathrm{u} /$ ), and the consonant cluster of /xw-/ (Shushtari-Dezfuli). Moreover, the opposition between NP. / $\mathrm{x} /$ and Luri / $\mathrm{h} /$ (see: section 4.1) appears to be a reversion of the infrequent phonological change of $/ \mathrm{h} />/ \mathrm{x} /$ from MP to NP (for example: MP. $h u s ̌ k$ 'dry' > NP. xušk) that has even occurred in Luri words of Arabic origin. The deletion of final $/ \mathrm{n} /$ (MacKinnon, 2011) which is frequent in Luri dialects has also evidence in ENP (for more details, see: Bahar, 1389, p. 190; Lazard, 1963, p. 156-157). The insertion of $/ \mathrm{i} / \mathrm{(}>/ \mathrm{e} /)$ before the initial consonant clusters has occurred in Luri as well:

1) MP. sp- > ENP. isp- (cf. MP. spēd 'white', Bakhtiari espēd, Mn. P. sepid,)

2) MP. st- > ENP. ist- (cf. MP. stadan 'to take', Bakhtiari estayden, Mn. P. setadan)

3) MP. šk- > ENP. išk- (cf. MP. škastan 'to break', Bakhtiari eškasten, Mn. P. šekastan)

4) MP. šn- > ENP. išn- (cf. MP. šnāxtan 'to know, to recognize', Shushtari(11) ešnāxtan, Mn. P. šenâxtan)

Besides a shared MP basis, non-ergativity is another feature of both NP and Luri that reveals their close typological relationship by separating them from MP and its closer daughters, i.e. Fars dialects. On this basis, it can be concluded that Luri just like Khorassani Dari, has lost ergativity on the way out of Fars province, while the more conservative dialects of Fars have remained ergative.
In addition to non-ergativity, ${ }^{(12)} \mathrm{NP}$ and Luri share the following grammatical structures, among others, not attested in MP:

1) present and past perfect formed by the auxiliary verbs of ast 'is' and $b \bar{u} d$ 'was' ( $e$ and $b \bar{\imath}$ in Luri)(see: 4.3.4)

2) the optative mood made analogically from the $3^{\text {rd }}$ person singular of the MP present subjunctive.

3) present perfect subjunctive (with $b \bar{a} \bar{s}$ - in Persian and $b \bar{u}$ - in Luri, as in NP. xward-a bāšad; Bakhtiari xard-e būhe).

4) the plural suffix $-h \bar{a}$ (from the MP adverb suffix $-\bar{\imath} h \bar{a})$

5) the loss of the superlative suffix -tom

Now that we have reviewed the common features between Luri and Persian (including MP, ENP and Mn. P), it is time to take a look at their lexical and grammatical differences. From the present authors' viewpoint, these can be divided into five groups namely Parthian elements, Luri-Kurdish features, phonetic reductions, analogical changes and the distinguishing features of Luri which will be discussed in the following sections.

\section{Parthian Elements}

Apart from Parthian elements that both Persian and Luri might share, Luri varieties are distinguished by their own Parthian features, i.e. the Bakhtiari $3^{\text {rd }}$ person singular pronoun ho (cf. Parthian hō; see: Rezai Baghbidi, 2006: 61), and the Boyer-Ahmadi past base maker - $\hat{a}(y)(<$ Parthian $\bar{a} d)$ (see: Teheri, 2016: 117) which has been - unlike $-\bar{a} d$ in Persian and some Luri dialects - very productive. The following are a number of common lexical items in Parthian and Luri:

Table 3 - Parthian lexical items in Bakhtiari

\begin{tabular}{|c|c|c|c|c|}
\hline & Parthian & MP & Mn. P & Bakhtiari \\
\hline $\begin{array}{c}\text { to bite } \\
\text { to send }\end{array}$ & $\begin{array}{c}\text { gaštan } \\
\text { frēštag 'angel' }\end{array}$ & $\begin{array}{c}\text { gastan } \\
\text { frēstādan }\end{array}$ & $\begin{array}{c}\text { gazidan } \\
\text { ferestâdan }\end{array}$ & $\begin{array}{c}\text { gašten } \\
\text { ferešnāden }\end{array}$ \\
\hline
\end{tabular}

\section{Luri-Kurdish Features}

Among Luri dialects, common features with Kurdish are more frequent in Feyli and Bakhtiari (perhaps via Feyli) as a result of their contact with the Kurdish-speaking area:

These, together with Lorī to the west and north, constitute the "Perside" southern Zagros group, as opposed to Kurdish dialects in the northern Zagros, with which Baktīārī shares a number of lexical and morphological items and phonological features, e.g., piā "man", korr "boy", bard "stone", mul "neck"; the topicalizer and vocative marker $\operatorname{ak}(\overline{\mathrm{u}})$; the "Zagros- $d$ ", i.e., the intervocalic lenisation, or loss, of $d$ (Windfuhr, 1988, p. 559).

Table 4 provides other examples of cognates in Kurdish and Bakhtiari: 
Table 4 - Basic vocabulary of Kurdish and Bakhtiari vs. Modern Persian

\begin{tabular}{|c|c|c|c|}
\hline & Mn. P & Kurdish ${ }^{(13)}$ & Bakhtiari \\
\hline mother & mâdar & dâyik & dā \\
udder & pestân & gwân & gūn \\
branch & šaxe & lik & lek \\
\hline
\end{tabular}

One typological characteristic of northwestern Iranian Languages - including Kurdish - that is found in Feyli dialect is the phoneme /ž/. Table 5 contains examples of the correspondence of the southwestern $/ z /$ to $/ \check{z} /$ :

Table 5 - Evidence for /ž/ in Luri

\begin{tabular}{|c|c|c|}
\hline & Feyli ${ }^{(14)}$ & Bakhtiari \\
\hline eyelash & merženg & merzeng (cf. MP. mijag) \\
crab & kerženg & kerzeleng (cf. MP. karzang) \\
giddy, dizzy & gižz & gēz \\
gum & ževi & zedi (cf. MP. zadūg) \\
ant & meriž & mürēz \\
\hline
\end{tabular}

\section{Phonetic Reductions}

Being also common in modern Persian dialects and accents, phonetic reductions reflect the linguistic economy principle. However, standard Modern Persian, thanks to its conservative writing traditions, still uses the unreduced forms. For instance, the Mn. P. dud 'smoke', mâdiyun 'mare' and xâhar 'sister' in Luri dialects have reduced to $d \bar{l}, m \bar{u} n$ and $x \bar{a} r$. This type of change specifically accounts for the formation of the present-day Luri prepositions and past tense verbs. For example, the Luri (be) $s \bar{l}$ 'for' ${ }^{(15)}$ and (be) men-e 'in, inside' are undoubtedly reductions of the ENP. $b a$ sōy-i 'to, toward, for' and ba mayān- $i$ 'in the middle of'. The pre-modern Luri wa sū (= be sī) (see: Sadeghi, 1996, p. 13) verifies the suggested Persian origin (for attestations of $b a s \bar{o} y-i$ 'for' in Classical Persian texts, see, Anvari, 1382, p. 4286). Men-e is also used in modern Khorassani dialects of Persian (see: Monchi-Zadeh, 1990, p. 125), far from the Lurispeaking region.

In Bakhtiari, as a Luri dialect, some past tense verbs also have reduced forms, e.g., $\operatorname{rah}(\mathrm{do}) \mathrm{m}$ 'I went', $r a h(d e) n$ 'they went', $b \bar{\imath}(d o) m$ 'I was', $b \bar{\imath}(d e) n$ 'they were'.

\section{Analogical Changes}

These changes have not been studied well and probably occurred since the divergence of Luri from MP. The formation of past perfect in Southern Luri dialects - according to MacKinnon (2011) - seems to have been generated by analogy. It is possible that Southern Luri present perfect has also formed through a similar process. As you see in Table 6, the Bakhtiari auxiliary verbs $e$ 'is' and $b \bar{\imath}$ 'was' that originally mark the $3^{\text {rd }}$ person singular, have seemingly extended to the other persons:

Table 6 - Bakhtiari present and past perfect

\begin{tabular}{|c|c|c|}
\hline & Present Perfect & Past Perfect \\
\hline $\begin{array}{c}1^{\text {st }} \text { Person Singular } \\
2^{\text {nd }} \\
3^{\text {rd }}\end{array}$ & $\begin{array}{c}\text { xard-ome 'I have eaten' } \\
x a r d-i(y) e \\
\text { xard } \boldsymbol{e}\end{array}$ & $\begin{array}{c}\text { xard-om } b \bar{\imath}{ }^{'} \mathrm{I} \text { had eaten' } \\
x a r d-\bar{\imath} b \bar{\imath} \\
\text { xard } \boldsymbol{b} \overline{\boldsymbol{\imath}}\end{array}$ \\
\hline $\begin{array}{c}1^{\text {st }} \text { Person Plural } \\
2^{\text {nd }} \\
3^{\text {rd }}\end{array}$ & $\begin{array}{l}\text { xard-īm e } \\
\text { xard-in e } \\
\text { xard-en e }\end{array}$ & $\begin{array}{l}\text { xard-īm } b \bar{\imath} \\
\text { xard-īn } b \bar{\imath} \\
\text { xard-en } b \bar{l}\end{array}$ \\
\hline
\end{tabular}


The fact that both Persian and Luri have developed the present and past perfect structures using cognates of the verbs $h$ - and baw- - in opposition to estād, est- 'to stand, to be' in MP present and past perfect (see: Amoozgar \& Tafazzoli, 1382, p. 78) - shows that they have been subject to similar changes during the transition to the new period.

Another significant analogy-based feature of Luri is the suffix -est found in the past stem of intransitive verbs, such as Bakhtiari verbs lars-est 'trembled', hand-est 'laughed'. In Middle Persian, ist attaches to present stems passivized by the suffix -īh, giving past stems (see: Amoozgar \& Tafazzoli, 1382 , p. 80), as in MP. kuš-īh-ist 'was killed'. It is obvious that the Luri -est comes from these MP passive verbs which can semantically be considered intransitive. Realizations of $-\bar{i} h$ are also seen in
Southern Luri verbs, such as Bakhtiari pehrest 'jumped', kahnest 'was plucked' (compare to their causative or transitive forms: per- $n-\bar{l} \delta$ 'made (sb/sth) jump', kan-d 'plucked'), and Boyer-Ahmadi pâšehēs 'was spattered', mâlehēs 'was rubbed' (compare to: pâš-an-ây 'spatterd', mâl-īy 'rubbed').

The Distinguishing Features of Luri

These are features that do not have clear etymologies, and are of the highest significance in the present study. At first glance, they indicate different origins for Luri and Persian, but if we explore their distribution (see Table 7) we find that many of them are not shared by all Luri varieties. Whether these are remains of a substratum or not is a matter of future studies, but at least they cannot be relied on to recognize a single language as Luri, particularly because other Iranian languages have them in common (see: notes 15-18).

Table 7 - Major distinguishing features of Luri

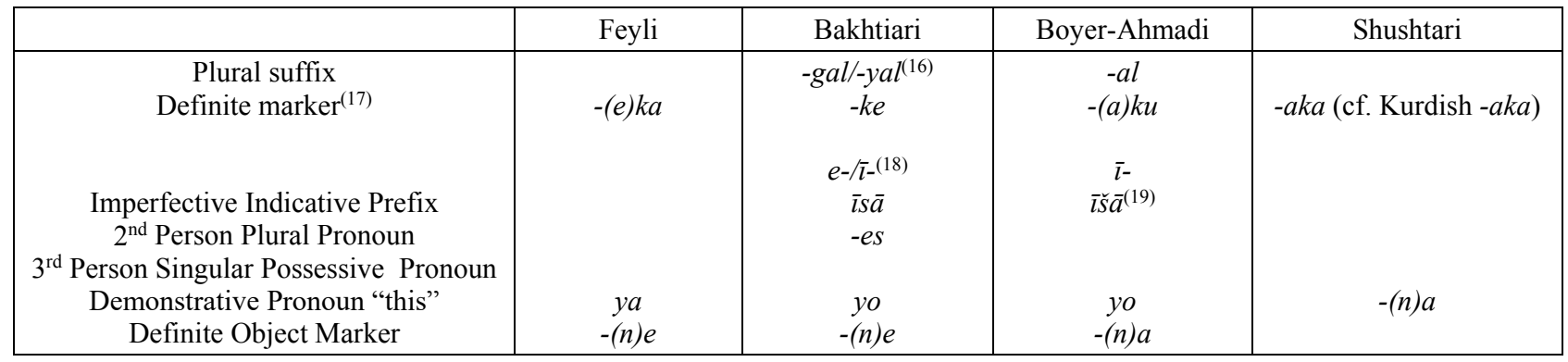

At the phonological level, the changes of $f t>$ $h d / h t, x t>h d / h t, m>w$ and $\bar{o} / \bar{u}>\bar{\imath}$ distinguish Luri from Persian, but their distribution, whether in Luri dialects or in other Iranian languages, shows, like that of the above elements, no homogeneity in Luri. The diffusion of the above changes in every Luri dialect is another point to be considered. For example, although Bakhtiari generally shows $f t>$ $h d$, the Bakhtiari words baften 'to knit, to weave', noft 'nose' and čaft 'knee joint, shin' have resisted this change or retained the original Persian forms.

\section{Conclusion}

The controversy over the relationship between Luri and Persian, which is of high significance in the classification of western Iranian dialects, results, as discussed in this article, from the clash between the diachronic and synchronic approaches toward the issue. That is, although Luri varieties are distinct languages from Persian, diacronichally, it is preferred to classify them as modern dialects of Middle Persian from which Modern Persian is derived separately. Apparently, during the new period Luri has retained more MP grammatical features than Modern Persian has (for example, verbal inflectional affixes, phonemes and phonological features), so it would be a fallacy to assume another parent language for Luri rather than Middle Persian. This relationship can be compared to that of Latin and Romance languages if we replace Latin with Middle Persian. To sum up, the authors believe that Luri is a direct continuation of dialects of Middle Persian which, in the course of centuries, has undergone language changes other than those of Modern Persian, turning it into the form of a different language. But in the deepest layers, no typological differences can be recognized between Luri and Persian. The close relationship between Luri and Persian is also proved by the fact that they share a number of common features (namely non-ergativity, verbal structures and some 
suffixes) which distinguish them from Middle Persian. Moreover, a large number of distinguishing features of Luri can be reduced into Parthian and Kurdish borrowings, phonetic reductions and analogical changes, and do not necessarily denote a different origin for Luri. Luri dialects also have features not found in Persian but shared by other Iranian Languages - such as the imperfective indicative prefix $e-$. Blurring the boundaries of Luri/non-Luri, these cannot be relied upon to disprove the above theory. Non-linguistic information also supports this theory, especially the fact that there is almost no evidence for the existence of Lur tribe and Luri language before the $5^{\text {th }} / 11^{\text {th }}$ and the $8^{\text {th }} / 14^{\text {th }}$ centuries respectively. Etymologically, the word Luri refers to a region after which its residents have been called, although, as today's dialectal evidence demonstrates, there is no linguistic unity behind it. Therefore, it seems that the term Luri Language has been coined particularly on the basis of sociohistorical, rather than linguistic, facts, and -as it was proposed earlier - it does not refer to any proto-Luri, thus, it sounds more acceptable to classify Luri dialects - and probably other dialects of southwestern Iran - as modern varieties of Middle Persian.

\section{Notes}

${ }^{1}$ Note that these dialects are spoken by tribes bearing the same name.

${ }^{2}$ Unfortunately, we could not find the original source of this quotation

${ }^{3}$ For Bakhtiari examples, see: Madadi, 1392; Taheri, 2010. Note that in some cases we have corrected the transcriptions of our sources to conform to our adopted method.

${ }^{4}$ This phenomenon is a relic of earlier stages of borrowing the consonant /q/ from Arabic, when it was still difficult for the Bakhtiaris to produce it.

${ }^{5}$ Cf. MP. angust (for MP examples, see: MacKenzie, 1986).

${ }^{6}$ Cf. MP. must

${ }^{7}$ Cf. MP. sōr

${ }^{8}$ In pre- and early Islamic sources, the name Kurd refers to tribal people in general, regardless of their language. For an example of this usage, see: Kārnāmak i Artaxšēr i Pāpakān, 1390, p. 4.

${ }^{9}$ For etymologies of Lūr, see: Minorsky, 1986, p. 821.

${ }^{10}$ Sadeghi (2003, p. 122) suggests the MP $-\bar{i} h \bar{a}$ as the origin of the plural suffix -iyâ in Larestani dialect of Fars province.

${ }^{11}$ See: Niroumand, 2535.

${ }^{12}$ As to the syntax of Luri in general, Lecoq $(1989$, p. 345) states that "la syntaxe des dialectes lori est dans l'ensemble celle du person parlé et n'appelle donc aucune remarque particulière".

${ }^{13}$ See: Kalbasi, 1385.

${ }^{14}$ For Feyli examples, see: Izadpanah, 1381.

${ }^{15}$ MacKinnon (1995, p. 353) has suggested the same etymology for $s \bar{l}$.

${ }^{16}$ This suffix is not confined to Luri and it is also used in Fars dialects, such as Davānī (see: Mahamedi, 1996, p. 130). Even in Bakhtiari, it is not the most productive plural suffix.

${ }^{17}$ In spoken Persian, $-e$ is the equivalent for this marker (see: MacKinnon, 2011).

${ }^{18}$ This prefix is also found in other Iranian dialects (see: Kalbasi, 1382, pp. 80-81).

${ }^{19}$ The infrequent ENP pronoun $\bar{\imath} \check{s} m \bar{a}$ 'you (plural)' (see: Ravaghi, 1381, p. 38) seems to be the origin of the Luri pronoun.

\section{Abbreviations}

$\begin{array}{ll}\text { Ar. } & \text { Arabic } \\ \text { EJP } & \text { Early Jewish-Persian } \\ \text { ENP. } & \text { Early New Persian } \\ \text { Mn. P. } & \text { Modern Persian } \\ \text { MP. } & \text { Middle Persian } \\ \text { NP. } & \text { New Persian }\end{array}$

\section{References}

Al-Dimashqi. (1923). Nukhbat al-dahr fi 'Ajā'ib al-Barr wa al-Bahr [Book of Wonders of the Land and Sea]. by A. Mehren. Leipzig: Harassowitz.

Amanolahi-Baharvand, E. (1385/2006). Qom-e Lor [Lur Tribe: Research into the Ethnic Unity and Geographic Distribution of the Lurs in Iran]. Tehran: Āgah. 
Amoozgar, J., \& Tafazzoli, A. (1382/2003-2004). Pahlavi Language: Literature, Grammatical Sketch, Texts and Glossary. Tehran: Moin Publishing Co. [in Persian].

Anonby, E. J. (2003).Update on Luri: How Many Languages?. Journal of the Royal Asiatic Society, 13 (2), pp. 171-197.

Anonby, E. J. (2012). Sociolinguistic Status of Lori. In Encyclopedia Iranica. Online address: http://www.iranicaonline.org/articles/lori-language-ii

Anvari, H. (1382/2003-2004). Farhang-e bozorg-e sokhan [Sokhan's Grand Dictionary]. Tehran: Sokhan.

Asmussen, J. P. (1965). Judaeo-Persica II: The Jewish-Persian Law Report from Ahwāz, A. D. 1020. Acta Orientalia XXIX. pp. 49-60.

Bahar, M. (1389/2010-2011). Sabk-shenāsi yā tārikh-e tatavvor-e nasr-e Fārsi [The Stylistics or the history of the evolution of Persian prose]. Vol. 1. Tehran: Amirkabir.

Daryaee, T. (2009). Sasanian Persia: The Rise and Fall of an Empire. New York: I.B. Tauris \& Co. Ltd, in association with the Iran Heritage Foundation.

Dehkhodâ, A. (1373/1993-1994). Loghatnâme [Encyclopedic Dictionary]. Chief Editors: Mohammad Mo'in and Jafar Shahidi. Vol. 12. Tehran: Tehran University Publications.

Fakhraddin Gorgani. (1381/2002-2003). Vīs u Rāmīn. Edited by Mohammad Roshan. Tehran: Sedā-ye mo āser.

Izadpanah, H. (1381/2002-2003). Farhang-e Lori [Luri Dictionary]. Tehran: Asātir.

Kalbasi, I. (1382/2003-2004). Neshāne-ye estemrār dar lahje-hā va guyesh-hā-ye Irāni [Continuity Marker in Iranian Accents and Dialects]. Dialectology, 1, pp. 76-97.

Kalbasi, I. (1385/2006-2007). Kordian Dialect in Mahābād. Tehran: Pazhuheshgah-e olum-e ensani va motaleat-e farhangi. [in Persian].

Karamainî. (2006). Takmilat al-Asnâf: A Dictionary of Classical Arabic-Persian. Vol. 1. Edited by Ali Ravaghi. In collaboration with Zulaykha Azimi. Tehran: Society for the Appreciation of Cultural Works and Dignitaries.

Kārnāmak i Artaxšêr i Pāpakān [Book of the deeds of Ardashir, son of Papak]. (1390/2011-2012). Translated into Persian by

B. Farahvashi. Tehran: University of Tehran Press.

Lazard, G. (1963). La Langue des Plus Anciens Monuments de la Prose Persane. Paris: Librairie C. Klincksieck.

Lecoq, P. (1989). Les dialects du sud-ouest. Compendium Linguarum Iranicarum. Herausgegeben von Rüdiger Schmitt.

Wiesbaden: L. Reichert.

MacKenzie, D. N. (1968). An Early Jewish-Persian Argument. Bulletin of the School of Oriental and African Studies, 31 (2), pp. 249-269.

MacKenzie, D. N. (1968). A Concise Pahlavi Dictionary. London: Oxford University Press.

MacKinnon, C. (1995). Dezfūlī and Šūštarī Dialects. In Encyclopaedia Iranica. Edited by E. Yarshater. Vol. VII. Costa Mesa,

California: Mazda Publishers. pp. 351-354.

MacKinnon, C. (2011). Lori Dialects. In Encyclopaedia Iranica. Edited by E. Yarshater. Vol. VII. Costa Mesa, California:

Mazda Publishers. Online address: http://www.iranicaonline.org/articles/lori-dialects

Madadi, Z. (1392/2013). Vāzhehnāmeh-ye zabān-e Bakhtiāri [Lexicon of the Bakhtiari Language]. Esfahan: Zohrāb Madadi.

Mahamedi, H. (1996). The Davān̄̄ Dialect. In Encyclopaedia Iranica. Edited by: E. Yarshater. Vol. VII. Costa Mesa, California:

Mazda Publishers. pp. 129-132.

Minorsky, V. (1986). Lur. In Encyclopaedia of Islam. Vol. 5. Leiden: Brill. pp. 821-826.

Monchi-Zadeh, D. (1990). Wörter aus Xurâsân und ihre Herkunft, in: Acta Iranica, 29. Leiden: Brill.

Niroumand, M. B. (2535/1976-1977). Vāzhenāme-yi az guyesh-e Shushtar [A Lexicon of the dialect of Shushtar]. Tehran:

Language Academy of Iran.

Paul, L. (2013). Early New Persian. In Encyclopaedia Iranica. Edited by: E. Yarshater. Vol. VII. Costa Mesa, California: Mazda

Publishers. Online address: http://www.iranicaonline.org/articles/persian-language-1-early-new-persian

Ravaghi, A. (1381/2002-2003). Zeyl-e farhang-hä-ye Fārsi [An Appendix to Persian Dictionaries]. In collaboration with Maryam Mir-Shamsi. Tehran: Hermes.

Rezai Baghbidi, H. (2006). A Manual of Parthian (Arsacid Pahlavi). With a Parthian Word-List by Askar Bahrami. Tehran: Qoqnus Publications. [in Persian].

Sadeghi, A. A. (1375/1996). A Short Text in Luri from the $11^{\text {th }}$ Century A.H. Iranian Journal of Linguistics, 13 (1\&2), pp. 9-15.

Sadeghi, A. A. (1382/2003). About Larestani Dialect. Iranian Journal of Linguistics, 18 (1), pp. 120-138.

Taheri, E. (2010). Baxtiyārī Dialect of Kührang. Tehran: Institute for Humanities and Cultural Studies. [in Persian].

Taheri, E. (2016). Lori Dialect of Boirahmad. Tehran: Institute for Humanities and Cultural Studies. [in Persian].

Windfuhr, G. (1988). The Baktīārī Dialect. In Encyclopaedia Iranica. Edited by E. Yarshater. Vol. III. Costa Mesa, California: Mazda Publishers. pp. 559-561.

Windfuhr, G., \& Perry, J. (2009). Persian and Tajik. In The Iranian Languages. Edited by: Gernot Windfuhr. London: Routledge. pp. 416-544.

Zhukovski, V. A. (1922). Materialy dlja izučenija persidskih narečij [Materials for the Study of Persian Dialects]. III. Petrograd (reprint: Tehran 1976). 